\title{
Square Scientists and the Excluded Middle
}

Citation for published version (APA):

Mody, C. C. M. (2017). Square Scientists and the Excluded Middle. Centaurus, 59(1-2), 58-71. https://doi.org/10.1111/1600-0498.12147

Document status and date:

Published: 01/01/2017

DOI:

10.1111/1600-0498.12147

Document Version:

Publisher's PDF, also known as Version of record

\section{Please check the document version of this publication:}

- A submitted manuscript is the version of the article upon submission and before peer-review. There can be important differences between the submitted version and the official published version of record.

People interested in the research are advised to contact the author for the final version of the publication, or visit the DOI to the publisher's website.

- The final author version and the galley proof are versions of the publication after peer review.

- The final published version features the final layout of the paper including the volume, issue and page numbers.

Link to publication

\footnotetext{
General rights rights.

- You may freely distribute the URL identifying the publication in the public portal. please follow below link for the End User Agreement:

www.umlib.nl/taverne-license

Take down policy

If you believe that this document breaches copyright please contact us at:

repository@maastrichtuniversity.nl

providing details and we will investigate your claim.
}

Copyright and moral rights for the publications made accessible in the public portal are retained by the authors and/or other copyright owners and it is a condition of accessing publications that users recognise and abide by the legal requirements associated with these

- Users may download and print one copy of any publication from the public portal for the purpose of private study or research.

- You may not further distribute the material or use it for any profit-making activity or commercial gain

If the publication is distributed under the terms of Article $25 \mathrm{fa}$ of the Dutch Copyright Act, indicated by the "Taverne" license above, 


\title{
Square Scientists and the Excluded Middle
}

\author{
Cyrus C. M. ModY*
}

\begin{abstract}
The historiography on American science and technology in the 1970s is still small, yet there are already three distinct strands of work: studies of countercultural scientists, portrayed as enacting or advocating 'groovy' research; studies of the politically polarized debate pitting conservative and libertarian 'cornucopianists' against environmentalists and modelers forecasting resource scarcity; and studies of the early commercialization of technoscience (e.g., biotechnology) that took off in the 1980s. Left out, I argue, are a class of 'square scientists' with little sympathy for the counterculture, and yet open to (even eager for) a new kind of science oriented to the same problems activists said they wanted science to solve: pollution, mass transit, housing, biomedicine, disability technologies, pedagogical machines, etc. Square scientists at places like NASA and Texas Instruments adapted military-industrial-academic templates to a wide variety of socially 'relevant' topics in the 1970s. Yet square scientists still looked to the military-industrial complex for allies, rather than to countercultural colleagues. This potential middle ground remained excluded - contributing, in large part, to the failure of schemes to reorient US R\&D to civilian social problems, and to the invisibility of the squares in today's historical accounts.
\end{abstract}

Keywords. Commercialization of research, counterculture, resource scarcity

\section{Getting Past 1970}

Historians have been interested in postwar American science and technology for quite some time. Indeed, the outlines of historiography on postwar science were set during World War Two itself, in Henry DeWolf Smyth's (1945) Atomic Energy for Military Purposes and Henry Guerlac's (1987 [1947]) Radar in World War Two. The weaponization, bureaucratization and physics-ization of science were already apparent in those real-time histories (Schwartz, 2008; Dennis, 1994), and continued to be important themes once the postwar period became an acceptable topic for historians.

Yet for many years the 'postwar' period ended in 1970. Many works on Cold War US science and technology abruptly stop in the early 1970s (Leslie, 1993; Lowen, 1997; Zachary, 1999; Westwick, 2003; Akera, 2006; Haring, 2006; Lécuyer, 2006). The themes of these works - Big Science, the military-industrial-complex, the supremacy of physics - were difficult to sustain past 1970. Since the 1970s, the military-industrial-complex has not dominated American science as it did in the early Cold War, physics has declined in funding and

\footnotetext{
*Faculty of Arts and Social Sciences, Maastricht University, Postbus 616, 6200 MD, Maastricht, Netherlands

E-mail: c.mody@maastrichtuniversity.nl
} 
influence relative to biology, and Big Science has become harder to fund (Riordan, Hoddeson and Kolb, 2015). To get past 1970, historians of American science and technology need new narratives.

Fortunately, in the past decade fascinating histories of science and technology in the 1970s have started to appear. In the next sections I describe three storylines that these works offer in place of earlier narratives about American postwar science and technology: countercultural and New Left science and technology; backlash science and the political polarization of the resource scarcity debate; and commercialized technoscience. These storylines are emic categories. That is, they are categories that I, as an historian of post-1970 American science, have derived from studies that my colleagues and I have actually written. An etic categorization derived by stepping outside the perspective of the history of science community and positing all possible narratives of post-1970 US science is beyond my scope. My empirical examples and citations to the literature are somewhat weighted toward the physical and engineering sciences, but the themes of the storylines I identify are apparent in histories of the social and life sciences as well. Finally, I only claim confidence in applying these storylines to the USA, though some of the works I cite take a more transnational scope. An important topic for future research would be to identify which aspects of these storylines were specific to the USA, and which were entangled in global developments (Agar, 2008).

My aim is twofold. First, I identify some anomalies in how these literatures represent science and technology in the 1970s, and draw connections among these storylines that have so far been missed. Second, I posit a category of actor - 'square scientists' - that is neglected in the dominant post-1970 storylines. I outline what little the historiography says about square scientists and sketch what a full-fledged narrative about them might say.

\section{Storylines 1 and 2: Counterculture and Resource Scarcity}

I will summarize the first two storylines together, since they are entangled in curious ways. Recent works on countercultural science and technology have captured the field's - and public's - imagination (Turner, 2006; Moore, 2008; Medina, 2011; Kaiser, 2012; Kaiser and McCray, 2016). There is something deeply appealing about hippie maverick scientists talking to dolphins and ghosts, taking LSD, bridging science and art. Of course, these works also make an important argument. Previous generations pictured the counterculture as an anti-science 'revolt against reason', (Richard Lyman, president of Stanford, quoted in Anonymous, 1971). It is, therefore, eye opening to discover that the counterculture and New Left were, in fact, enthusiastic about science. Many cutting-edge discoveries of the past half-century can be traced to people who believed in extrasensory perception, astral projection and (weirdest of all) Science for the People.

Still, it's important not to exaggerate the importance or innocence of the counterculture and New Left. There is some sense in which hippies 'saved' physics and LSD begat 
Apple and the internet. Yet the counterculture and New Left also left behind many broken careers when reforms - often chaotic and ad hoc - failed to change 'the system'. The quest for a more just science yielded uplifting partnerships forged in the hot tubs of Esalen (Kripal, 2007) and the Black Panther clinics of Portland (Nelson, 2013). But reformers also cultivated homicidal and megalomanical allies, from Ira Einhorn to Chairman Mao.

These movements also enraged some unpleasant enemies, from Edward Teller to Augusto Pinochet. Thus, the second emerging storyline of post-1970 science and technology (mainly) in the USA explores the polarizing conflict between scientists and engineers aligned with the New Left and those aligned with nascent movement conservatives. The roots of that divide were varied - Vietnam, nuclear strategy, the supersonic transport, etc. But the core disagreement concerned resource scarcity (Egan, 2007; Badash, 2009; McCray, 2013; Hamblin, 2013; Sabin, 2013; Macekura, 2015). The ideas that earth's resources were finite, that a growing human population would accelerate resource exhaustion, and that humans can trigger rapid, catastrophic, global changes were promoted by a disciplinarily diverse group: from electrical engineer Jay Forrester to ecologist Paul Ehrlich to astronomer Carl Sagan. In response, 'cornucopianist' scientists and engineers from economics (Julian Simon) to nanotechnology (Eric Drexler) organized to combat fears of resource scarcity.

The hard-core scientific cornucopianists, though, were physicists. The modern environmental movement emerged from nuclear testing controversies in the 1950s (Lutts, 1985). Thus, the discipline that claimed credit for nuclear weapons also yielded the most vociferous critics of environmentalism. Conservative physicists - many associated with Edward Teller and Frederick Seitz - mobilized across a range of controversies (Oreskes and Conway, 2010): anti-ballistic missile defense (for it); the ozone hole and acid rain (don't worry); nuclear winter (couldn't happen); global warming (bad science); cigarettes and cancer (smoke 'em if you got 'em).

\section{Anomalies}

The literatures on countercultural science and the resource scarcity debate are recent enough that some obvious questions have yet to be addressed. I would point out two such anomalies in particular. First, not all Cold Warrior scientists and engineers sided with Teller. Even some co-inventors of the hydrogen bomb and the nuclear weapons complex - Harold Brown, Herbert York, Hans Bethe, Richard Garwin - were scathing critics of anti-ballistic missile defense (Slayton, 2013). Bethe, and even more Garwin, were champions of socially responsible, societally engaged research. The scientists most visibly opposed to nuclear testing were Linus Pauling and Barry Commoner - future leaders in the peace and environmental movements but deeply embedded in the military-industrial-complex before the mid-1950s. Carl Sagan, the most prominent scientist associated with the nuclear winter hypothesis, was similarly supported by the 
military before the mid-1960s. Even Noam Chomsky received military funding through the early 1960s (Harris, 1974). If everyone started out allied with the military, why did some move left and some right in the late 1960s? The answer advanced so far is unsatisfying: Seitz et al. felt betrayed by their colleagues over Vietnam. So why did their colleagues 'betray' them?

My second anomaly derives from the obligatory paragraph near the end of books on countercultural science and technology where it is revealed that the protagonists are, today, staunch reactionaries. Obviously, the politics of the 1970s were fluid. For example, at the Stanford Artificial Intelligence Laboratory, the director, John McCarthy, moved from red-diaper baby to toxic reactionary conspiracy theorist while his deputy, Les Earnest, 'who had worked in government intelligence, would move to the left' (Markoff, 2009). Still, it is striking that as the US scientific establishment has become more liberal, many of those who once challenged that establishment from the left now align with the American right.

Indeed, anti-Establishment scientists have even adopted the technoscientific imaginaries of conservative cornucopianists. Cornucopianists like Teller were sure humans couldn't run out of resources or destroy the environment because innovation could overcome any resource deficit. They based that belief on their own attempts to weaponize the environment. They envisioned modifying earth's atmosphere, oceans, space environment and even geography, and justified those plans by asserting that free-market nations could adapt while authoritarian regimes could not. Even thermonuclear war would leave the earth habitable for capitalists, while anthropogenic climate change would lead to economic growth!

Perversely, Teller et al. were less optimistic that democracy could adapt. They routinely subverted democratic oversight, purged liberal colleagues and supported the overthrow of democratic regimes (Kirsch, 2005; McMillan, 2005). So it's perhaps no surprise that their views have converged with countercultural figures who were similarly unsympathetic to democracy and similarly confident that innovation would provide. But it is mildly surprising that both groups have adopted the same technologies and scientific views.

Take nuclear power: readers of the Whole Earth Catalog wanted to leave a small footprint, but these days Stewart Brand (2010) agrees with the defense establishment that nuclear energy is a good bet, even if it can poison whole regions. Or, take climate change: for Freeman Dyson, it seemed a problem when he was counterculture-curious in the 1970s, but now that he's a darling of Wired he's sure it's not (Brower, 2010). Similarly, Richard Branson doesn't think democracy is capable of a solution to climate change, so why not let billionaires fund exactly the same geoengineering technologies that Teller's allies promoted in the early Cold War (Nicholson, 2013)?

Perhaps there's no anomaly here. As Fred Turner argues, Dr. Strangelove and the hippies bonded over their dislike of liberal democracy. When the communes collapsed, many former inhabitants became interested in technologies - space colonies, nuclear power, the internet - that are actually or potentially catastrophic to the environment (Ensmenger, 2015) and probably poisonous to democracy as well. But if the extremities of the political 
spectrum converged after 1970, what about the center? My guess is, if we want to understand why groovy scientists moved rightward we need to know more about what scientists on the center-left and center-right did.

\section{Storyline 3: Commercialized Technoscience}

We also, I think, need to know more about markets, since that's where political discourse moved in the late 1970s and 1980s. Fortunately, the third well-developed storyline about post-1970 science focuses on commercialization of research. Here, historians of science are catching up to management scholars, anthropologists, sociologists, economists and even philosophers (Rabinow, 1996; Mowery et al., 2004; Powell and Owen-Smith, 2004; Murray, 2004; Colyvas, 2007). Much of this work focuses on academic biotech entrepreneurs, but in fact commercialization of academic research began to increase in the 1970s across all disciplines from agriculture to music (Mody and Nelson, 2013). Some scholarship celebrates the heroes of high-tech (Berlin, 2005; Jones, 2005; Hughes, 2011), while others condemn (Mirowski, 2010).

Curiously, many critics claim commercialization was the consequence of an 'epochal break' in attitudes toward science and technology, possibly in the spring of 1980 (Gibbons et al., 1994; Ziman, 2000; Forman, 2007; Nordmann, Radder, and Schiemann, 2011), for which neoliberal economists and their political allies can be blamed. But academic scientists started turning toward the market around 1970, well before neoliberal policies had much influence. Paula Stephan (2012) shows that the policies that have been most deleterious to research were changes in pension schemes and retirement ages enacted in the 1990s. These shifted money toward older scientists to continue existing research and away from younger scientists proposing new topics. Neoliberal intellectual property policies from the 1980s had much less effect. Stephan also quantitatively documents another important shift, this time in the mid-1960s: science policymakers moved from viewing universities as sources of personnel to viewing them as sources of discoveries. Qualitatively, that fits with Glen Asner's (2006) work on Project HINDSIGHT, Elizabeth Popp Berman's (2012) on the 'market university', and Hyungsub Choi's (Mody and Choi, 2013) discovery that ARPA grant officers moved from a personnel-production frame to a discovery-production frame in evaluating university contracts in the mid-1960s.

Thus, rather than one sudden rupture, economization of science built up from many small turns that accumulated between roughly 1965 and 1995. One particularly important turning point has largely been ignored by historians of science: the Japanese government's 1975 announcement of a crash program in semiconductor manufacturing, which legitimated state intervention in science to boost economic competitiveness in the USA (and, to some extent, in the UK, France, West Germany and the Netherlands). True neoliberals would disapprove of such interventions; but, over time, the elevation of economic 
competitiveness considerations that accompanied such interventions reinforced a neoliberal agenda.

I find Sabel and Zeitlin's 'historical alternatives' approach (Zeitlin, 2007) from business history useful in understanding the market turn. In their view, organizations continually experiment with their modes of production, and evaluate their own and competitors' experiments. There aren't sudden, totalizing moves from one mode to another; rather a consensus gradually builds that some experiments work better than others. For American science, after 1965 the postwar (and especially post-Sputnik) mode of organizing research became politically and fiscally unsustainable. So organizations experimented with new modes. Over time a consensus formed that the experiments that worked best brought academic and corporate research closer to the market. What neoliberal economists and politicians did was to weed out non-market reforms; but both the market and non-market reforms were initially experimented with for reasons quite independent of neoliberalism. Moreover, neoliberals never managed to entirely weed out the early Cold War mode of research, nor all of the non-market reforms to that mode. Many scientists and engineers still pursue curiosity-driven and/or public-sector-oriented research with no thought of patenting or monetizing their work.

Aside from the epochal break/neoliberalism issue, the other great open question about commercialization is how much it owed to the counterculture. Popular histories, in particular, cast academic entrepreneurs and high-tech pioneers (Markoff, 2005; Isaacson, 2011) as norm-defying mavericks who subvert the Establishment and therefore have a natural affinity with the counterculture. Academic historians have been more circumspect, with the partial exception of Eric Vettel (2006), who argues that New Left demands that scientists 'research life not death' incentivized molecular biologists' turn toward biomedical applications which then facilitated their leap into industry.

Nicolas Rasmussen (2014), however, dismisses Vettel's claims that the 'spirit of '68' fostered biotech. I'm sympathetic to Rasmussen's alternative picture of biotech as a natural evolution of incremental progress within molecular biology. But I also think Rasmussen throws the baby out with the bathwater. Vettel doesn't draw a plausible connection from Vietnam-era unrest to canonical biotech firms like Genentech, Hybritech or Amgen, but he does capture the countercultural milieu of an earlier firm, Cetus. And his portrayal of the pressures on scientists to reform - from left and right and from top-down and bottom-up - helps makes sense of the proliferation of institutional experiments in American science in the early 1970s, of which the experiments in moving closer to the market have been the most durable.

That said, the depiction of high-tech and academic entrepreneurs as countercultural mavericks is too simple. To take a famous example, yes, the personal computer owed something to Ted Holm's Computer Lib and Steve Jobs' dropping acid - but it owed even more to rather square electrical engineers and, surprisingly, clinicians (November, 2012). There would be no Apple without fast integrated circuits; the attitude of the people who produced those circuits was summarized by Gordon Moore of Intel: 'we are really the 
revolutionaries in the world today - not the kids with the long hair and beards who were wrecking the schools a few years ago' (in Bylinsky, 1973). Similarly, while some academic entrepreneurs probably believed they were fighting the Establishment, many others were what Sonali Shah and Mary Tripsas (2007) call 'accidental entrepreneurs'. They wandered toward the market because they liked the challenge of starting a company or didn't think there was another way to make their inventions available to - for instance - children with impaired sight or hearing. Some academic entrepreneurs of the 1970s whom I've encountered were Establishment icons with military haircuts and politics to match. Others were influenced by the counterculture, but not part of it. As a former associate of one put it, 'he wasn't a hippie but he was relaxed'. The widow of another noted that despite what might be inferred from his interest in parapsychology, his daily uniform was a black suit, skinny black tie, and white, short-sleeve, button-down shirt. These were pretty square people, even if their experiments sometimes put them at odds with the system.

\section{Storyline 4: The Science of the Squares}

Which brings me to my fourth storyline: the role of - literally - button-down scientists and engineers in an era of turmoil and experimentation. My label for these people is 'square scientists', a term encompassing people who were not part of the youth counterculture or New Left, but who also were not part of the backlash. These were scientists and engineers whose views about alternative lifestyles ranged from curiosity to indifference to impatience, but who - unlike Fred Seitz and company - weren't so enraged by the counterculture or New Left that they sought to burn down the house of science. The term best fits people who, previously, were deeply embedded in the military-industrial-academic complex. Some remained so during the 1970s, but many moved permanently away from the military. Given the demographics of American science then and now, the term is skewed toward white, straight, middle class, middle-aged men. I'm not trying to rehabilitate the reputation of this class. Rather, I'm pointing out that most scientists and engineers weren't part of the counterculture or the backlash, and that we need storylines about these people to place the other storylines in context.

There is already a literature on square scientists, but it is invisible as a literature. Edited volumes, conference panels, co-citation patterns, book reviews, etc. lend visibility to the storylines on the counterculture, resource scarcity debate, and market turn. As far as I know, there haven't been volumes or panels on the squares. Views on what square scientists did during the 1970s are correspondingly fractured. Some (Kevles, 1978) imply that Establishment scientists simply accepted a loss of authority and abandoned their most ambitious plans. Others (Westwick, 2007; Westfall, 2008) describe a science and engineering community that suffered through the 1970s and was reborn in the Reagan

era. But we also have studies of veterans of the military-industrial-academic complex who believed that institutions, practices, discoveries, technologies and personnel associated 
with defense R\&D should be reoriented to problems of civil society in the 1970s. Jennifer Light (2003) promoted this thesis in From Warfare to Welfare: Defense Intellectuals and Urban Problems in Cold War America. Unfortunately, her book hasn't spawned a literature the way, say, Fred Turner's From Counterculture to Cyberculture has. Indeed, the nearest follow-on to Light's book is Peter Sachs Collopy's (2015) history of countercultural video art - i.e., a bending back to storyline \#1.

Conversely, there are works (Lécuyer, 2005) that examine square scientists and engineers in the marketplace - i.e., a bending back to storyline \#3 - without ever noticing that the counterculture existed. These are authors I'm indebted to, yet glossing over the upheavals in American science and society of the late 1960s and early 1970s is unsatisfying. Even if square scientists did not participate in the counterculture, New Left, or the anti-war and civil rights movements, they did observe what was going on around them and in many cases changed what they were doing as a result. Some responded by trying to make themselves hip. For instance, Bell Labs manager Jack Morton brought countercultural ideas about 'innovation' into industry (Wisnioski, 2016), while another Bell Labs engineer, Billy Klüver, partnered with Robert Rauschenberg and other artists (McCray, 2016). Others, such as Stanford applied physicist Calvin Quate, simply rode the wave of funding as it shifted from defense to socially 'relevant' areas like pollution, mass transit, public housing, biomedicine and disability (Mody, 2012).

Quite a few, though, sincerely re-evaluated their research portfolios and decided that working on socially relevant topics would bring more personal satisfaction than continuing to do research funded by the military. Of those, many turned to civilian topics out of revulsion for the war in Southeast Asia and a dawning realization of science's complicity in society's ills. Here, for instance, is an excerpt from an interview with a Stanford engineering professor from 1971:

Q. Why do you want to move into the areas that you don't seem to be able to move into?

A. There are several reasons. First, I think it is possible to get stale by devoting too much of one's "creative life" to a relatively narrow specialty as I sometimes feel I have been doing. Second, I think there is unquestionably a fairly direct relationship between a great deal of my students' and my research and military technology applications. Up until 5 or 6 years ago that fact didn't bother me very much and I was satisfied that the problem seemed to me to have an inherent interest. Today I'm certainly not as happy as I was then about many aspects of U.S. Foreign Policy and the domination of the military in the national scene... I would like to find research activity which seems to me to have a really constructive social potential. ${ }^{1}$

Yet it's too simple to equate the turn toward social relevance with an inclination to the anti-war left. In research on Stanford, I've found that scientists affiliated with the center-right were, if anything, more likely to broaden their research portfolios than those on the center-left. Outside academia, the political valence of social relevance was even more confused. Aerospace companies rebranded as public transportation specialists, and nuclear weapons laboratories retooled to improve public housing. Take, for instance, NASA's Manned [sic] Spacecraft Center in Houston (today the Johnson Space Center). JSC was 
traditionally one of NASA's more politically conservative field sites, due to its Southern location and connection to the all-military astronaut corps. With the end of Apollo, though, the Nixon administration pressured JSC into collaborating with the Department of Housing and Urban Development to produce cheaper, more energy-efficient utility systems for multifamily housing - yet most engineers in that project welcomed what they considered an intellectually stimulating challenge. Moreover, that top-down project was accompanied by a host of bottom-up essays into 'public sector' research: adapting the lunar rover for use by quadriplegics, working with public health officials in New Mexico to deliver better health care to Native American reservations, collaborating with medical faculty and social services agencies in Texas to feed people too poor and/or elderly to purchase food at a supermarket. These projects evaporated with the launch of the space shuttle and the Reagan administration's interest in commercializing space - but for a few years in the 1970s, even as square an organization as JSC was committed to socially relevant R\&D (Figure 1).

Or take the co-inventor of the integrated circuit, Jack Kilby. It's hard to imagine a more square scientist than Kilby - deeply patriotic, a veteran, a suburban white, straight Texan. His biography quotes Kilby's self-narrative thus: 'I grew up among the industrious descendants of the western settlers of the American Great Plains' (in Millis, 2008, p. 5). Another anecdote indicates his politics: 'like so many Texans, Jack didn't like [Bill] Clinton' (Millis, 2008, p. 91). Yet, when Kilby became an independent inventor in 1970, the technologies that most drew his attention were educational machines (a technology beloved by the Bay Area counterculture, too) and, above all, solar power. Indeed, Kilby spent the remainder of his career championing solar power, and the rest of his life embittered that Texas Instruments kept his solar power inventions off the market.

\section{The Excluded Middle}

Further research is needed to know how representative Kilby and NASA were. Their importance, however, is easier to see. Kilby was an influential pillar of the defense establishment and future Nobel laureate. NASA was a global brand which absorbed almost $4.5 \%$ of the annual federal budget in the mid-1960s. As such, they cast new light on the other literatures I've surveyed. With respect to Storyline \#1, these examples show that 'countercultural' science was not exclusive to the counterculture. Much 'groovy' science of the 1970s looked just like non-groovy science. We need to reevaluate countercultural science in light of what the squares were doing. Maybe there was some specifically countercultural science, but there were also structural factors that encouraged everyone - hippies and squares, hawks and doves - to modify their research in similar ways.

With respect to Storyline \#2, these examples suggest reconsideration of the polarized politics of science and resource scarcity in the 1970s. Works in Storyline \#2 emphasize the zealotry of their protagonists. To be sure, there were moments - particularly from the summer of 1968 through the spring of 1969 - when the American scientific community 


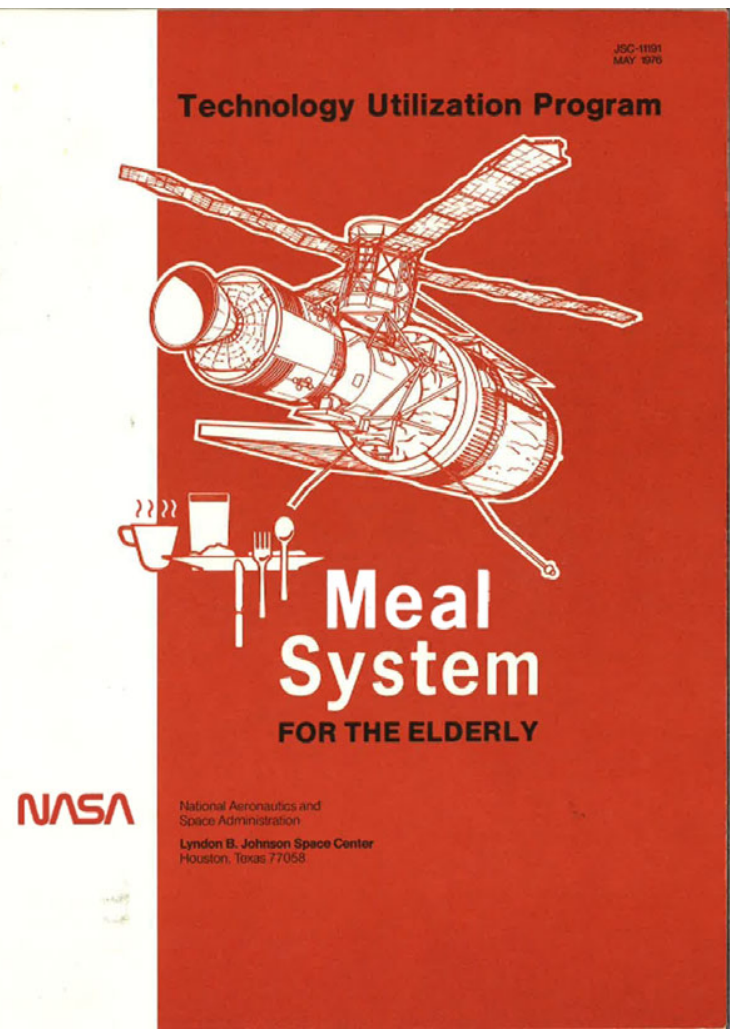

Fig. 1. Cover of the final report of the Meal System for the Elderly project carried out by NASA Johnson Space Center in collaboration with the University of Texas, Martin Marietta, and a Texas affiliate of Meals on Wheels. The project took food delivery technologies which had been engineered for astronauts' use in space and adapted them for delivery (by mail, volunteer, or social worker) to elderly Texans with limited ability to leave their homes to buy food.

seemed as likely to break into open warfare as the rest of American society. Yet most of the scientists I've interviewed or encountered in the archives were not zealots. Many were uncomfortable with or annoyed by those they disagreed with, but few sought to purge them - at first. Kilby, for instance, grudgingly engaged with the solar energy community, with whom he had little in common - though after Reagan was elected Kilby told the new administration that all the Department of Energy's solar experts should be fired.

Similarly, the National Research Council panel that advised the Department of Energy from 1975 to 1977 on how to organize its new Solar Energy Research Institute included Bill Nierenberg and Frederick Seitz - two of the 'merchants of doubt' whom Oreskes and Conway describe as conspiring to undermine the scientific consensus on smoking, acid rain, ozone depletion, strategic defense, nuclear winter and global warming. It's surprising, then, that they would aid the formation of a federal solar energy facility. The 
eight-member panel also included Edward Ginzton of Stanford and Richard Garwin of IBM. Garwin's center-left reputation I've alluded to; Ginzton's leanings were possibly even further left given his friendship with the theosophists, socialists, union organizers and pacifists affiliated with his old firm, Varian Associates (Lécuyer, 2006). Yet I've seen no indication the Solar Energy Research Institute committee was polarized in the way Storyline \#2 might suggest - though given the Reagan administration's decimation of SERI in the 1980s, cornucopianist antipathy toward the institute must have arisen later.

The closure of SERI also offers a clue to reassessing Storyline \#3. Works on commercialized technoscience argue something important happened in 1980. But what, exactly? I believe the significance of that year lies in the winnowing of socially relevant science, and in a hardening of attitudes among conservative scientists and engineers. In the 1970s, individuals like Kilby, and institutions like NASA, happily broadened their portfolios to include aiding the poor and disabled. But over the years, their frustrations with such projects mounted - they didn't believe their collaborators were any good, funding was unpredictable, the people they thought they were helping never seemed grateful or enthused. So in the 1980s they abandoned social relevance. They didn't quite return to early Cold War habits, though. Institutional experiments that brought researchers closer to the market were preserved. To give an example from NASA: some historians (Jirout, 2015) argue that the Landsat earth observation satellites were an early beachhead within NASA for neoliberal proposals for commercialization of space. Yet in the 1970s the Landsat group at JSC was mostly focused on aiding Native American communities, public health researchers and environmentalists - i.e., public-sector users, rather than commercial markets. There was no epochal break, only an epochal filter. Landsat spanned 1980, but Landsat activities oriented to the public interest did not.

Finally, my two examples cue us to examine the 'excluded middle'. Square scientists were in the middle of American science in the 1970s: they didn't participate much in the counterculture, but weren't implacably hostile to it. Many squares reformed their research in the 1970s in small ways and large - becoming more interdisciplinary, less dependent on the military, more open to a diverse, inclusive laboratory, more interested in using science to benefit society and the environment. These people have been excluded in the historiography thus far, in favor of more colorful characters on the left and right.

In part, though, the historiography reflects the middle's exclusion at the time. Few people wanted to be seen occupying the middle ground in the 1970s. Jack Kilby, for instance, wanted solar power to succeed, but he could only imagine collaborating on solar power with military-industrial allies who preferred nuclear energy. Kilby never offered environmental justifications for solar power, and he dismissed the technical competence of those who did. Similarly, individual NASA engineers were intrigued by the technical challenges of adapting space capsule technology to multifamily housing - but their employer was adamant that it was a space agency and not an organization dedicated to solving society's problems. Square scientists and organizations themselves avoided the middle ground - which explains why that middle is invisible in today's historiography. 
I've argued here, though, that our understanding of American science in the 1970s will be muddled if we don't examine what that middle was up to, and how over time it became a precarious space to occupy.

\section{NOTE}

1. Memo from Stanton Glantz to Stanford Research Committee, 3 March 1971, re: Interview with Engineering Professor, Stanford University Archives and Special Collections, SU Sponsored Projects Office records (SC 344 ACCN 1987-130), Box 1, Folder 1.

\section{REFERENCES}

Agar, J. (2008) What happened in the sixties? British Journal for the History of Science, 41, 567-600.

Akera, A. (2006) Calculating a natural world: scientists, engineers, and computers during the rise of US cold war research (Cambridge: MIT Press).

Anonymous (1971, January 27) Revolt against reason can have 'ominous consequences'. Campus Report, p. 1.

Asner, G. R. (2006) The Cold War and American industrial research. Unpublished PhD thesis, Carnegie Mellon University.

Badash, L. (2009) A nuclear winter's tale: science and politics in the 1980s (Cambridge: MIT Press).

Berlin, L. (2005) The man behind the microchip: Robert Noyce and the invention of Silicon Valley (New York: Oxford University Press).

Berman, E. P. (2012) Creating the market university: how academic science became an economic engine (Princeton: Princeton University Press).

Brand, S. (2010) Stewartship, C-Lab, 2, 68-71.

Brower, K. (2010, December) The danger of cosmic genius. The Atlantic, pp. 48-62.

Bylinsky, G. (1973, November) How Intel won its bet on memory chips. Fortune, pp. 143-144.

Collopy, P. S. (2015) The revolution will be videotaped: making a technology of consciousness in the long 1960s. Unpublished $\mathrm{PhD}$ thesis, University of Pennsylvania.

Colyvas, J. (2007) From divergent meanings to common practices: Institutionalization processes and the commercialization of university research. Unpublished $\mathrm{PhD}$ thesis, Stanford University.

Dennis, M. A. (1994) Echoes of the past. Henry Guerlac and radar's historiographic problem, in: O. Blumtritt, H. Petzold and W. Aspray (eds.) Tracking the history of radar (New Brunswick: IEEE), pp. 285-298.

Egan, M. (2007) Barry commoner and the science of survival: the remaking of American environmentalism (Cambridge: MIT Press).

Ensmenger, N.(2015) The materiality of the virtual: an environmental history of computing. Paper presented at SHOT SIGCIS meeting held in Albuquerque, October 11.

Forman, P. (2007) The primacy of science in modernity, of technology in postmodernity, and of ideology in the history of technology, History and Technology, 23, 1-152.

Gibbons, G., Gibbons, M., Limoges, C., Nowonty, H., Schwartzman, S., Scott, P. and Trow, M. (1994) The new production of knowledge: the dynamics of science and research in contemporary societies (London: Sage).

Guerlac, H. E. (1987 [1947]) Radar in world war II (College Park: American Institute of Physics).

Hamblin, J. D. (2013) Arming mother nature: the birth of catastrophic environmentalism (New York: Oxford University Press).

Haring, K. (2006) Ham radio's technical culture (Cambridge: MIT Press).

Harris, F. (1974) [online] The development of the linguistics program at the Massachusetts Institute of Technology. Available online at: ling50.mit.edu/harris-development (accessed 12 December, 2017).

Hughes, S. S. (2011) Genentech: the beginnings of biotech (Chicago: University of Chicago Press).

Isaacson, W. (2011) Steve jobs (New York: Simon \& Schuster).

Jirout, B. (2015) Civil remote sensing for sale: commercializing Landsat image use, 1978-1989. Paper presented at SHOT annual meeting, Albuquerque, October 10.

Jones, M. P. (2005) Biotech's perfect climate: the hybritech story. Unpublished PhD thesis, UC San Diego. 
Kaiser, D. (2012) How the hippies saved physics: science, counterculture, and the quantum revival (New York: W. W. Norton).

Kaiser, D. and McCray, W. P. (eds.) (2016) Groovy science: knowledge, innovation, and American counterculture (Chicago: University of Chicago Press).

Kevles, D. J. (1978) The physicists: the history of a scientific community in modern America (New York: Knopf). Kirsch, S. (2005) Proving grounds: project plowshare and the unrealized dream of nuclear earthmoving (New Brunswick: Rutgers University Press).

Kripal, J. J. (2007) Esalen: America and the religion of no religion (Chicago: University of Chicago Press).

Lécuyer, C. (2005) What do universities really owe industry? Minerva, 43(1), 51-71.

Lécuyer, C. (2006) Making Silicon Valley: innovation and the growth of high tech, 1930-1970 (Cambridge: MIT Press).

Leslie, S. W. (1993) The cold war and American science: the military-industrial-academic complex at MIT and Stanford (New York: Columbia University Press).

Light, J. S. (2003) From warfare to welfare: defense intellectuals and urban problems in cold war America (Baltimore: Johns Hopkins University Press).

Lowen, R. (1997) Creating the cold war university: the transformation of Stanford (Berkeley: University of California Press).

Lutts, R. H. (1985) Chemical fallout: Rachel Carson's Silent Spring, radioactive fallout, and the environmental movement, Environmental Review, 9(3), 210-255.

Macekura, S. J. (2015) Of limits and growth: the rise of global sustainable development in the twentieth century (New York: Cambridge University Press).

Markoff, J. (2005) What the dormouse said: how the sixties counterculture shaped the personal computer industry (London: Penguin).

Markoff, J. (2009, December 8) Optimism as artificial intelligence pioneers reunite. New York Times, p. D4.

McCray, W. P. (2013) The visioneers: how a group of elite scientists pursued space colonies, nanotechnologies, and a limitless future (Princeton: Princeton University Press).

McCray, W. P. (2016) Big in Japan: technology, art, and Osaka's expo '70. Paper presented at SHOT meeting, Singapore, June 24.

McMillan, P. J. (2005) The ruin of J. Robert Oppenheimer (New York: Viking).

Medina, E. (2011) Cybernetic revolutionaries: technology and politics in Allende's Chile (Cambridge: MIT Press).

Millis, E. (2008) Jack St. Clair Kilby: a man offew words (Dallas: Ed Millis Books).

Mirowski, P. (2010) Science-Mart: privatizing American science (Cambridge: Harvard University Press).

Mody, C. C. M. (2012) Conversions: sound and sight, military and civilian, in: T. Pinch and K. Bijsterveld (eds.) Oxford handbook of sound studies (Oxford: Oxford University Press), pp. 224-248.

Mody, C. C. M. and Choi, H. (2013) From materials science to nanotechnology: institutions, communities, and disciplines at Cornell University, Historical Studies in the Natural Sciences, 43(2), 121-161.

Mody, C. C. M. and Nelson, A. (2013) A towering virtue of necessity': computer music at Vietnam-era Stanford, Osiris, 28, 254-277.

Moore, K. (2008) Disrupting science: social movements, American scientists, and the politics of the military, 1945-1975 (Princeton: Princeton University Press).

Mowery, D. C., Nelson, R. R., Sampat, B. and Ziedonis, A. A. (2004) Ivory tower and industrial innovation: University-industry technology transfer before and after the Bayh-Dole Act in the United States (Stanford: Stanford Business Books).

Murray, F. (2004) The role of academic inventors in entrepreneurial firms: sharing the laboratory life, Research Policy, 33, 643-659.

Nelson, A. (2013) Body and soul: the black panther party and the fight against medical discrimination (Minneapolis: University of Minnesota Press).

Nicholson, S. (2013) The promises and perils of geoengineering, in: E. Assadourian and T. Prugh (eds.) State of the world 2013: is sustainability still possible (Dordrecht: Springer), pp. 317-331.

Nordmann, A., Radder, H. and Schiemann, G. (eds.) (2011) Science transformed? Debating claims of an epochal break (Pittsburgh: University of Pittsburgh Press). 
November, J. A. (2012) Biomedical computing: digitizing life in the United States (Baltimore: Johns Hopkins University Press).

Oreskes, N. and Conway, E. M. (2010) Merchants of doubt: how a handful of scientists obscured the truth on issues from tobacco smoke to global warming (New York: Bloomsbury Press).

Powell, W. W. and Owen-Smith, J. (2004) Knowledge networks as channels and conduits: the effects of spillovers in the Boston biotechnology community, Organization Science, 15, 5-21.

Rabinow, P. (1996) Making PCR: a story of biotechnology (Chicago: University of Chicago Press).

Rasmussen, N. (2014) Gene Jockeys: life science and the rise of biotech enterprise (Baltimore: Johns Hopkins University Press).

Riordan, M., Hoddeson, L. and Kolb, A. W. (2015) Tunnel visions: the rise and fall of the superconducting supercollider (Chicago: University of Chicago Press).

Sabin, P. (2013) The bet: Paul Ehrlich, Julian Simon, and our gamble over Earth's future (New Haven: Yale University Press).

Schwartz, R. P. (2008) The making of the history of the atomic bomb: Henry Dewolf Smyth and the historiography of the Manhattan Project. Unpublished PhD thesis, Princeton University.

Shah, S. and Tripsas, M. (2007) The accidental entrepreneur: the emergent and collective process of user entrepreneurship, Strategic Entrepreneurship Journal, 1, 123-140.

Slayton, R. (2013) Arguments that count: physics, computing, and missile defense, 1949-2012 (Cambridge: MIT Press).

Smyth, H. D. (1945) Atomic energy for military purposes (Princeton: Princeton University Press).

Stephan, P. (2012) How economics shapes science (Cambridge: Harvard University Press).

Turner, F. (2006) From counterculture to cyberculture: Stewart Brand, the whole earth network, and the rise of digital utopianism (Chicago: University of Chicago Press).

Vettel, E. J. (2006) Biotech: the countercultural origins of an industry (Philadelphia: University of Pennsylvania Press).

Westfall, C. (2008) Retooling for the future: launching the advanced light source at Lawrence's laboratory, 1980-1986, Historical Studies in the Natural Sciences, 38(4), 569-609.

Westwick, P. J. (2003) The national labs: science in an American system, 1947-1974 (Cambridge: Harvard University Press).

Westwick, P. J. (2007) Into the black: JPL and the American space program, 1976-2004 (New Haven: Yale University Press).

Wisnioski, M. (2016) How the industrial scientist got his groove: entrepreneurial journalism and the fashioning of technoscientific innovators, in: D. Kaiser and W. P. McCray (eds.) Groovy science (Chicago: University of Chicago Press), pp. 337-365.

Zachary, G. P. (1999) Endless frontier: Vannevar Bush, engineer of the American Century (Cambridge: MIT Press).

Zeitlin, J. (2007) The historical alternatives approach, in: G. Jones and J. Zeitlin (eds.) Oxford handbook of business history (New York: Oxford University Press), pp. 120-140.

Ziman, J. (2000) Real science: what it is and what it means (New York: Cambridge University Press). 